\title{
Erratum to: Diagnosis of genital herpes simplex virus infection in the clinical laboratory
}

Jérôme LeGoff ${ }^{1 *}$, Hélène Péré ${ }^{2,3}$ and Laurent Bélec ${ }^{2,3}$

\section{Erratum}

We recently published a review on genital herpes diagnosis in the Virology Journal entitled "Diagnosis of genital herpes simplex virus infection in the clinical laboratory" [1]. Tables 1 and 2 were adapted from an article of Domeika and colleagues published in Eurosurveillance journal [2], with the formal permission of the Editor of Eurosurveillance. However, the article of Domeika and colleagues was not correctly cited as a source, due to a typographical error, and the correct reference is [18] (and not [9]) for both Table 1 and 2. Furthermore, it came to light that some sentences in the Abstract and the main body of the article were duplicated from previously published articles, including Strick et al., 2006 [3-8]. We apologize for any inconvenience caused.

The fundamental aim and basic purpose of our extensive and original review on genital herpes diagnosis was to give up-to-date information regarding the laboratory diagnosis of genital herpes that medicine laboratory needs to implement best assays in their diagnosis strategy [1]. We provide information about HSV-1 and HSV-2 characteristics that are critical for both serological and direct diagnosis (Key structure elements for diagnosis).

We provided information regarding the collection, transport and storage of clinical specimens for herpes diagnosis that have to be respected to ensure a good sensitivity. In the field of molecular assays, we summarized the state of the art including the most recent publications on Food and Drug Administration (FDA)-approved assays to help in the selection of a technique that is the most suitable according to the laboratory equipment and organization. We presented the current FDA approved serological assays with specific comments on the interpretation of index values and gave detailed guideline for the use of serological assays in clinical practice. Finally, for patients under antiviral treatment, we presented a practical

\footnotetext{
* Correspondence: jerome.le-goff@sls.aphp.fr

${ }^{1}$ Université Paris Diderot, Sorbonne Paris Cité, Microbiology laboratory, Inserm U941, Hôpital Saint-Louis, APHP, 1 Avenue Claude Vellefaux, Paris
} 75010, France

C 2015 LeGoff et al. Open Access This article is distributed under the terms of the Creative Commons Attribution 4.0 International License (http://creativecommons.org/licenses/by/4.0/), which permits unrestricted use, distribution, and reproduction in any medium, provided you give appropriate credit to the original author(s) and the source, provide a link to the Creative Commons license, and indicate if changes were made. The Creative Commons Public Domain Dedication waiver (http://creativecommons.org/publicdomain/zero/1.0/) applies to the data made available in this article, unless otherwise stated. guideline for therapeutic monitoring and summarized in a one table all the resistance mutations known for HSV-1 and HSV-2.

\section{Author details \\ ${ }^{1}$ Université Paris Diderot, Sorbonne Paris Cité, Microbiology laboratory, Inserm U941, Hôpital Saint-Louis, APHP, 1 Avenue Claude Vellefaux, Paris 75010, France. ${ }^{2}$ Laboratoire de Microbiologie, hôpital Européen Georges Pompidou, Assistance Publique-Hôpitaux de Paris, Sorbonne Paris Cité, Paris, France. ${ }^{3}$ Faculté de Médecine Paris Descartes, Université Paris Descartes (Paris V), Sorbonne Paris Cité, Paris, France.}

Received: 16 September 2015 Accepted: 16 September 2015 Published online: 13 October 2015

\section{References}

1. LeGoff J, Péré H, Bélec L. Diagnosis of genital herpes simplex virus infection in the clinical laboratory. Virol J. 2014;11:83.

2. Domeika M, Bashmakova M, Savicheva A, Kolomiec N, Sokolovskiy E, Hallen A, et al. Eastern European Network for Sexual and Reproductive Health (EE SRH Network): Guidelines for the laboratory diagnosis of genital herpes in eastern European countries. 2010. p. 15. Euro Surveill.

3. Gupta R, Warren T, Wald A. Genital herpes. Lancet. 2007;370:2127-37.

4. Strick $L B$, Wald $A$. Diagnostics for herpes simplex virus: is $P C R$ the new gold standard? Mol Diagn Ther. 2006;10:17-28.

5. Ustaçelebi S. Diagnosis of herpes simplex virus infections. J Clin Virol. 2001:21:255-9.

6. Van Wagoner NJ, Hook EW. Herpes diagnostic tests and their use. Curr Infect Dis Rep. 2012;14:175-84.

7. Wald A, Ashley-Morrow R. Serological testing for herpes simplex virus (HSV)-1 and HSV-2 infection. Clin Infect Dis. 2002;35 Suppl 2:S173-182.

8. Workowski KA, Berman S. Centers for Disease Control and Prevention (CDC): Sexually transmitted diseases treatment guidelines, 2010. MMWR Recomm Rep. 2010;59:1-110.

\section{Submit your next manuscript to BioMed Central and take full advantage of:}

- Convenient online submission

- Thorough peer review

- No space constraints or color figure charges

- Immediate publication on acceptance

- Inclusion in PubMed, CAS, Scopus and Google Scholar

- Research which is freely available for redistribution \\ ( Biomed Central}

